\title{
HUBUNGAN ANTARA EFIKASI DIRI DENGAN KEMAMPUAN PENGAMBILAN KEPUTUSAN KARIR SISWA MAN 2 KOTA BENGKULU
}

Agus Apriansyah, Hadiwinarto, Arsyadani Mishbahuddin

Prodi Bimbingan dan Konseling, Fakultas Keguruan dan Ilmu Pendidikan

Universitas Bengkulu

agusbk2018@gmail.com, hadiwin@unib.co.id, arsyadani@unib.ac.id

\begin{abstract}
ABSTRAK
Penelitian ini bertujuan untuk mendeskripsikan efikasi diri siswa Madrasah Aliyah Negeri 2 Kota Bengkulu, untuk mendeskripsikan kemampuan pengambilan keputusan karir siswa Madrasah Aliyah Negeri 2 Kota Bengkulu, dan untuk mendeskripsikan hubungan efikasi diri dengan kemampuan pengambilan keputusan karir siswa Madrasah Aliyah Negeri 2 Kota Bengkulu. Populasi penelitian ini adalah siswa kelas XII yang berjumlah 336 siswa, sampel berjumlah 185 siswa yang diambil dengan teknik simple random sampling. Alat pengumpulan data berupa kuesioner efikasi diri dan koesioner pengambilan keputusan karir. Analisis data menggunakan teknik korelasi product moment. Hasil penelitian menunjukkan bahwa ada hubungan positif dan signifikan antara efikasi diri dengan kemampuan pengambilan keputusan karir siswa Madrasah Aliyah Negeri 2 Kota Bengkulu. Nilai diterminasi ( $\mathrm{r}_{\text {square }}$ ) sebesar 0,338 dapat diartikan efikasi diri memberikan sumbangan efektif sebesar 33,8\% terhadap kemampuan pengambilan keputusan karir sedangkan sisanya 66,2\% dipengaruhi oleh faktor lain.
\end{abstract}

Kata kunci: efikasi diri, kemampuan pengambilan keputusan karir.

\begin{abstract}
The research was aimed to make description self efficacy students in Madrasah Aliyah Negeri 2 Kota Bengkulu, to make description how the students career decision making abilities in Madrasah Aliyah Negeri 2 Kota Bengkulu, and to know is correlation between self efficacy and students career decision making abilities in Madrasah Aliyah Negeri 2 Kota Bengkulu. The population in this research there are students of twelfth grade XII with the amount 336 students. Sample of were 185 students from random sampling technique. The instrument of this research was questionnaire self efficacy and student career decision making abilities. The data analysis was using technique of correlation product moment. The result of this research showed that there is correlation and significant between self eficacy and student career decision making abilities in Madrasah Aliyah Negeri 2 Kota Bengkulu. The score of determination ( $r_{\text {square }}$ ) was 0,338 It could be concluded that self efficacy gave effective impact toward career decision making abilities for $33,8 \%$ another hand $66,2 \%$ caused by another factors.
\end{abstract}

Keywords: self efficacy, career decision making abilities.

\section{Pendahuluan}

Di dalam UU No. 20 Th. 2003 Pasal 1: Pendidikan adalah usaha sadar dan terencana untuk mewujudkan suasana belajar dan proses pembelajaran agar peserta 
didik secara aktif mengembangkan potensi dirinya untuk memiliki kekuatan spiritual keagamaan, pengendalian diri, kepribadian, kecerdasan, akhlak mulia, serta keterampilan yang diperlukan dirinya, masyarakat, bangsa dan negara. Pendidikan memegang peranan penting dalam kelangsungan hidup suatu bangsa. Sunarto dan Hartono (2013 : 191) menyatakan bahwa banyak bangsa yang mengikuti prinsip pendidikan seumur hidup, artinya manusia itu senantiasa terus belajar sepanjang hayatnya.

Madrasah Aliyah (MA) adalah jenjang pendidikan menengah pada pendidikan formal di Indonesia, setara dengan sekolah menengah atas (SMA), yang pengelolaannya dilakukan oleh Kementerian Agama. Ketika siswa masuk jenjang MA siswa memilih salah satu dari 4 lulusan yang ada, yaitu Ilmu Alam, Ilmu Sosial, Ilmuilmu Keagamaan Islam, dan Bahasa. Lulusan Madrasah Aliyah dapat melanjutkan pendidikan ke perguruan tinggi umum, perguruan tinggi agama islam, atau langsung bekerja.

Saat berada di pendidikan Madrasah Aliyah (MA), umur siswa sekitar 15-18 tahun. Rentang usia ini berarti individu berada pada tahap perkembangan remaja. Istilah asing yang sering dipakai adalah pubertiet, adolescentia dan youth. Menurut WHO (dalam Sarwono dan Meinarno 2009:12) dinyatakan bahwa batasan remaja adalah seseorang yang berada pada umur 10-20 tahun.

Santrock (2009:19) menyatakan bahwa masa remaja adalah masa bagi mereka untuk mengambil keputusan mengenai masa depan, teman yang dipilih, dan apakah akan melanjutkan ke perguruan tinggi. Perkembangan karir remaja ada pada periode pilihan tentatif ( 11-17 tahun) yang ditandai oleh meluasnya pengenalan anak terhadap berbagai masalah dalam memutuskan pekerjaan apa yang akan dikerjakan pada masa mendatang.

Tugas memilih karir tampak besar selama periode ini, siswa mulai dihadapkan dengan berbagai pilihan-pilihan hidup. Menurut Nathan dan Hill (2012:31) bahwa pada tahap kehidupan school leavers (mereka meninggalkan suatu jenjang sekolah), pada tahap ini pilihan hidup remaja dipengaruhi oleh orangtua, teman sebayanya, dan akan mencoba identitas sendiri. Dalam proses perkembangan karir remaja sering 
mengalami berbagai masalah dan hambatan, baik yang berasal dari dalam diri maupun dari lingkungannya, bahkan kedua-duanya. Masalah yang berasal dari dalam diri antara lain: tidak mampu memilih jurusan yang sesuai dengan kemampuannya. Masalah yang berasal dari lingkungannya antara lain sering terjadi orangtua menghendaki atau memaksa anaknya memilih jurusan tertentu. Yang lebih parah ketika pilihan anak dan orangtua tidak saling mendukung, dapat muncul konflik dalam memilih karir.

Di dalam teori perkembangan karir yang dikemukakan oleh Super (dalam Winkel dan Hastuti, 2004: 632) dinyatakan bahwa kemampuan memilih dan mempersiapkan karir siswa berada pada tahap eksplorasi. Pada tahap ini, siswa sudah mulai mencari dan mengumpulkan berbagai informasi karir sesuai dengan bakat, minat potensi atau kemampuan yang dimiliki.

Studi pendahuluan yang dilakukan selama Magang III di Madrasah Aliyah Negeri 2 Kota Bengkulu, siswa sering konseling dengan guru BK mengenai masalah karirnya. Perasaan ragu-ragu, dan tidak dapat memutuskan untuk memasuki dunia kerja atau melanjutkan ke perguruan tinggi, atau memilih jurusan yang sesuai.

Berdasarkan hasil wawancara dengan guru BK tanggal 13 Desember 2017, ketika berada di kelas XII banyak siswa merasa kebingungan terhadap pilihan karirnya. Siswa merasa bingung kuliah atau langsung bekerja, belum ada kepastian terhadap program studi yang diinginkan atau masih banyak pilihan program studi, orangtua yang menginginkan program studi tertentu, belum tahu prospek karir program studi, belum tahu minatnya akan program studi tertentu, dan belum siap memasuki dunia kerja.

Wawancara yang dilakukan kepada 10 siswa Madrasah Aliyah Negeri 2 Kota Bengkulu, dapat diketahui bahwa 7 orang siswa masih bingung ingin kuliah atau langsung bekerja, kalau ingin bekerja bingung ingin bekerja apa, yang ingin melanjutkan kuliah mereka bingung memilih program studi apa, ingin mengikuti pilihan karir temannya, tidak mengetahui prospek karir dalam pilihan jurusan, dan ketidaksingkronan jurusan yang dijalani sekarang dengan jurusan karir selanjutnya. 
Ketidaksinkronan dalam keputusan karir merupakan salah satu akibat dari efikasi diri siswa yang rendah. Kasus siswa pada saat diwawancara mereka yang dari jurusan IPA memilih jurusan yang tidak sesuai misalnya ilmu komunikasi, hukum dan lain sebagainya yang seharusnya pilihan jurusan itu dipilih oleh siswa IPS. Sementara siswa cendrung akan mempertahankan jurusan yang telah dia pilih jika dia yakin akan kemampuannya. Hal ini sejalan dengan pendapat Dipa dan Alsa (2015:4) bahwa dengan memiliki efikasi diri dalam kemampuan pengambilan keputusan karir yang tinggi, maka individu akan mampu mempertahankan pilihan program studinya meskipun ada faktor lain kurang mendukung. Kondisi ini perlu dibuktikan melalui penelitian apakah ada hubungan atau tidak antara efikasi diri dengan kemampuan pengambilan keputusan karir.

Berdasarkan uraian, efikasi diri siswa diduga berhubungan dengan kemampuan pengambilan keputusan dalam kaitannya dengan pilihan karir yang telah ada sehingga perlu dilakukan penelitian dengan judul "Hubungan efikasi diri dengan kemampuan pengambilan keputusan karir siswa Madrasah Aliyah Negeri 2 Kota Bengkulu".

\section{Metode Penelitian}

Penelitian ini menggunakan desain kuantitatif korelasional. Menurut Riyanto (dalam Zuriah 2009: 56) menyatakan bahwa penelitian korelasional adalah penelitian yang melihat hubungan variabel atau beberapa variabel dengan variabel lain.

Penelitian ini dilaksanakan di Madrasah Aliyah Negeri 2 Kota Bengkulu, pada bulan Februari - Maret 2017. Populasi dalam penelitian ini adalah siswa kelas XII di Madrasah Aliyah Negeri 2 Kota Bengkulu berjumlah 336 siswa.

Teknik pengambilan sampel yang digunakan yaitu simple random sampling. Menurut Sugiyono (2011:120) menyatakan bahwa pengambilan sampel menggunakan simple randoom sampling yaitu pengambilan anggota sampel dari populasi dilakukan secara acak tanpa memperhatikan strata yang ada dalam populasi. Untuk menentukan banyak sampelnya menggunakan rumus Slovin,

$$
n=\frac{N}{1+N e^{2}}
$$


Keterangan:

(Prasetyo dan Jannah 2014:137)

$\mathrm{n}:$ Jumlah sampel yang dicari

$\mathrm{N}$ : Jumlah populasi

e : Nilai kritis (tingkat kesalahan $0,5 \%$ )

Berdasarkan perhitungan diketahui bahwa sampel minimal adalah 183 orang.

Peneliti menggunakan metode pengumpulan data melalui kuesioner atau angket. Menurut Sugiyono (2011: 199) menyatakan bahwa kuesioner atau angket adalah teknik pengumpulan data yang dilakukan dengan cara memberi seperangkat pertanyaan atau pernyataan kepada responden untuk dijawabnya. Alat ukur menggunakan skala Likert dengan empat pilihan jawaban.

Pengujian hipotesis dalam bentuk teknik perhitungan korelasi Product Moment dari Pearson dengan bantuan program SPSS (Statistical Package for the Social Sciences) for Windows 17.0.

\section{Hasil dan Pembahasan}

Azwar (1994:29) menyatakan bahwa suatu item yang baik jika nilai indeks pembeda memenuhi nilai Corrected Item Total Corelations sebesar 0,30 ke atas. Pengujian daya pembeda dilakukan dengan menggunakan program SPSS seri 17.

Berdasarkan hasil uji indeks pembeda angket efikasi diri yang disebarkan kepada 31 responden yang terdiri dari 40 item pernyataan diperoleh 31 item pernyataan yang dinyatakan baik dan 9 item pernyataan dinyatakan gugur. Sementara hasil uji indeks pembeda angket kemampuan pengambilan keputusan karir terdiri dari 40 item pernyataan diperoleh 32 item pernyataan yang dinyatakan baik dan 8 item pernyataan dinyatakan gugur.

Uji reliabilitas intrumen efikasi diri dan kemampuan pengambilan keputusan karir dengan menggunakan program SPSS versi 17.0 for windows dengan rumus Alpha Cronbach. Suatu data memiliki reliabilitas yang baik jika memenuhi syarat nilai Cronbach's Alpha minimal 0,70. Nilai Alpha Cronbach efikasi diri sebesar 0,912 $(>0,7)$ dan kemampuan pengambilan keputusan karir sebesar 0,918 $(>0,7)$ maka data memiliki reliabilitas yang baik.

\section{Tabel 1 Distribusi Frekuensi Skor Efikasi Diri}




\begin{tabular}{cccccc}
\hline No. & Interval & Frekuensi & Persentase(\%) & $\begin{array}{r}\text { Persentase } \\
\text { kumulatif }(\%)\end{array}$ & Kategori \\
\hline 1 & $>107$ & 19 & 10.3 & 10.3 & Sangat Tinggi \\
\hline 2 & $100-106$ & 44 & 23.8 & 34.1 & Tinggi \\
\hline 3 & $92-99$ & 69 & 37.3 & 71.4 & Sedang \\
\hline 4 & $85-91$ & 45 & 24.3 & 95.7 & Rendah \\
\hline 5 & $<85$ & 8 & 4.3 & 100.0 & Sangat Rendah \\
\hline
\end{tabular}

Berdasarkan Tabel 1 dari 185 siswa Madrasah Aliyah Negeri 2 Kota Bengkulu yang menjadi sampel penelitian yang termasuk kategori skor sangat tinggi sebanyak 19 orang dengan rentang skor diatas 107. Siswa kategori skor tinggi sebanyak 44 orang dengan rentang skor 100-106. Siswa yang termasuk kategori skor sedang sebanyak 69 orang dengan rentang skor 92-99. Siswa yang termasuk kategori skor rendah sebanyak 45 orang dengan rentang skor 85-91. Siswa yang termasuk kategori skor sangat rendah sebanyak 8 orang dengan rentang skor kurang dari 85 .

Tabel 2 Distribusi Frekuensi Skor

Kemampuan Pengambilan Keputusan Karir

\begin{tabular}{|c|c|c|c|c|c|}
\hline No. & Interval & frekuensi & $\%$ & $\begin{array}{l}\text { Persentase } \\
\text { kumulatif }\end{array}$ & Kategori \\
\hline 1 & $>116$ & 19 & 10.3 & 10.3 & Sangat Tinggi \\
\hline 2 & $108-115$ & 50 & 27.0 & 37.3 & Tinggi \\
\hline 3 & $100-107$ & 67 & 36.2 & 73.5 & Sedang \\
\hline 4 & 92-99 & 41 & 22.2 & 95.7 & Rendah \\
\hline 5 & $<92$ & 8 & 4.3 & 100.0 & Sangat Rendah \\
\hline
\end{tabular}

Berdasarkan Tabel 2 dari 185 siswa Madrasah Aliyah Negeri 2 Kota Bengkulu yang menjadi sampel penelitian yang termasuk kategori skor sangat tinggi sebanyak 19 orang dengan rentang skor diatas 116. Siswa kategori skor tinggi sebanyak 50 orang dengan rentang skor 108-115. Siswa kategori skor sedang sebanyak 67 orang dengan rentang skor 100-107. Siswa yang termasuk kategori rendah skor rendah sebanyak 41 orang dengan rentang skor 92-99. Siswa yang termasuk kategori skor sangat rendah sebanyak 8 orang dengan skor kurang dari 92. 
Sebelum melakukan uji product moment suatu alat uji menuntut dipenuhinya data yang berdistribusi normal. Suatu data dapat dikatakan nomal jika memiliki nilai signifikansi uji Kolmogorov Smirnov lebih besar dari 0,05 $(>0,05)$ dan sebaliknya data dinyatakan tidak normal jika nilai signifikansi uji Kolmogorov Smirnov kurang dari $0,05(<0,05)$ artinya data berdistribusi normal (Sarjono \& Julianita, 2013:64).

Nilai Kolmogorov Smirnov signifikansi untuk data efikasi diri sebesar 0,200>0,05 dan nilai signifikasi untuk data pengambilan keputusan karir sebesar 0,200 >0,05. Berdasarkan data tersebut, maka data skor efikasi diri dan kemampuan pengambilan keputusan karir berdistribusi normal.

Berdasarkan hasil pengujian hipotesis yang dilakukan untuk menguji hubungan antara efikasi diri dengan kemampuan pengambilan keputusan karir, menunjukan terjadinya hubungan yang positif dan signifikan antara efikasi diri dengan kemampuan pengambilan keputusan karir siswa kelas XII Madrasah Aliyah Negeri 2 Kota Bengkulu. Hal ini dibuktikan dengan nilai signifikansi efikasi diri dengan kemampuan pengambilan keputusan karir sebesar $0,000(\mathrm{P}<0,05)$ artinya bahwa ada hubungan yang signifikan antara efikasi diri dengan kemampuan pengambilan keputusan karir. Analisis uji Product Moment juga menunjukkan nilai koefisien Pearson Correlations sebesar 0,582 bernilai positif. Hal tersebut diartikan setiap meningkatnya 1 nilai efikasi diri maka nilai kemampuan pengambilan keputusan karir akan meningkat sebesar 0,582, semakin tinggi efikasi diri maka akan semakin tinggi kemampuan pengambilan keputusan karir siswa dan sebaliknya semakin rendah efikasi diri maka akan rendah kemampuan pengambilan keputusan karir.

Hasil uji hipotesis ini sesuai dengan pendapat Bandura (dalam Feist dan Feist 2010:212) menyatakan bahwa efikasi diri adalah keyakinan seseorang terhadap kemampuannya untuk melakukan perilaku kontrol terhadap keputusan yang mereka pilih. Efikasi diri memiliki pengaruh pada pemilihan perilaku individu ketika membuat keputusan. Keputusan yang dibuat didasarkan pada keyakinan individu terhadap kemampuannya dalam menghadapi kemungkinan-kemungkinan yang akan terjadi. Hal tersebut didukung oleh pendapat Taylor \& Betz (dalam Yowell, Andrews, dan Buzzette. 2010:1) menyatakan bahwa efikasi diri adalah kepercayaan individu tentang 
dirinya atau kemampuannya untuk melakukan tugas yang berkaitan dengan pengambilan keputusan.

Siswa yang memiliki efikasi diri ditandai dengan memiliki harapan yang tinggi terhadap diri mereka sendiri, mereka merasa optimis untuk menyelesaikan menyelesaikan tugas ataupun permasalahan yang dihadapi, memiliki keyakinan yang tinggi terhadap kemampuan yang ada dalam diri untuk mampu mengerjakan tugas secara mandiri, suka melakukan aktivitas-aktivitas baru yang menuntut siswa mengeluarkan kemampuannya, menanamkan usaha yang kuat dalam menghadapi kegagalan dan melakukan penilaian terhadap diri sendiri sehingga dapat membuat keputusan karir berdasarkan analisis tentang diri sendiri. Lebih lanjut siswa yang efikasi diri tinggi ditandai dengan kemampuan mengumpulkan dan menganalisis berbagai informasi, tuntutan dan prospek kedepan tentang karir. Hal tersebut sesuai dengan pendapat Parsons (dalam Winkel dan Hastuti 2004:92) menyatakan bahwa tiga faktor yang diperlukan dalam keputusan karir, yaitu: analisis terhadap diri sendiri, analisis terhadap bidang pekerjaan, dan mengadakan berpikir rasional.

Dalam penelitian ini juga ditemukan ada 8 siswa yang memiliki efikasi diri dan pengambilan keputusan karir yang rendah. Siswa yang yang memiliki efikasi diri sangat rendah kemungkinan memiliki pengalaman berupa kegagalan. Hal ini berdasarkan pendapat Bandura (dalam Feist \& Feist, 2010:214) yang mengatakan bahwa keberhasilan akan meningkatkan efikasi diri dan sebaliknya akan menurunkan efikasi diri ketika seseorang sudah memberikan usaha terbaik.

Hasil penelitian diatas sejalan dengan penelitian terdahulu yang pernah dilakukan oleh Ningrum dan Jati (2013:7) dengan judul hubungan antara efikasi diri dengan pengambilan keputusan karir pada mahasiswa semester akhir di Fakultas Ekonomika dan Bisnis Universitas Diponegoro. Hasil penelitian menunjukkan bahwa ada hubungan yang signifikan antara efikasi diri dengan pengambilan keputusan karir. Hal tersebut berarti tidak hanya efikasi diri mahasiswa yang mendukung pengambilan keputusan karir, tetapi juga pada siswa. Penelitian lain yang mendukung dilakukan oleh Siska (2015:39) dengan judul hubungan antara efikasi diri dengan Motivasi 
belajar siswa kelas X SMA negeri 9 Kota Bengkulu. Bahwa terdapat hubungan yang signifikan antara efikasi diri dengan Motivasi belajar siswa.

Kecenderungan siswa sudah memiliki pilihan karir yang akan dipilih dan memiliki kesiapan dalam pengambilan keputusan karir sehingga akan lebih siap dalam memutuskan dan menerima konsekuensi atas keputusan karir yang akan diambil. Keputusan karir dipengaruhi oleh berbagai faktor termasuk efikasi diri, hal ini berdasarkan pendapat Stanovich (dalam Santrock 2009:14) menyatakan bahwa pengambilan keputusan melibatkan keyakinan diri, percaya diri, pemikiran terdahulu, dan keterwakilan dari deskripsi. Pada penelitian ini terdapat temuan yang menunjukkan bahwa sumbangan variabel efikasi diri terhadap pengambilan keputusan karir sebesar 33,8\% sedangkan $66,2 \%$ faktor lain yang tidak dibahas dalam penelitian ini seperti pemikiran terdahulu, inteligensi, pergaulan teman sebaya, dan masyarakat.

Penelitian ini hanya membahas tentang efikasi diri, kemampuan pengambilan keputusan karir siswa, dan hubungan antara efikasi diri dengan kemampuan pengambilan keputusan karir siswa, penelitian hanya berlaku pada kelas XII tidak berlaku untuk kelas $\mathrm{X}$ dan XI, peneliti tidak mengkaji tindakan apa saja yang dapat dilakukan guru pembimbing untuk meningkatkan keyakinan terhadap kemampuan diri siswa serta kemampuan pengambilan keputusan karir siswa kelas XII Madrasah Aliyah Negeri 2 Kota Bengkulu.

\section{Kesimpulan}

Efikasi diri siswa kelas XII Madrasah Aliyah Negeri 2 Kota Bengkulu berada pada kategori sedang, Kemampuan Pengambilan keputusan karir siswa kelas XII Madrasah Aliyah Negeri 2 Kota Bengkulu berada pada kategori sedang, Hasil uji hipotesis menunjukkan adanya hubungan positif dan signifikan antara efikasi diri dengan kemampuan pengambilan keputusan karir siswa Madrasah Aliyah Negeri 2 Kota Bengkulu. Artinya semakin tinggi efikasi diri maka akan semakin tinggi kemampuan pengambilan keputusan karir. Besarnya sumbangan efektif pengaruh efikasi diri terhadap kemampuan pengambilan keputusan karir sebesar 33,8\% dengan 
demikian masih terdapat $66,2 \%$ faktor lain yang mempengaruhi kemampuan pengambilan keputusan karir siswa.

\section{Daftar Pustaka}

Azwar, S. (1994). Seleksi Aitem Dalam Penyusunan Skala Psikologi. Buletin Psikologi, 2(2), 26-33.

Dipa, A., \& Asmadi A. (2015). Pelatihan "PLANS" Untuk Meningkatkan Efikasi Diri Dalam Pengambilan Keputusan Karir. Universitas Gadjah Mada: Gadjah Mada Juornal of Professional Psychologi, 1(1), 1-17.

Feist, J., \& Feist, G. J. (2010). Teori Kepribadian. Jakarta: Salemba Humanika

Nathan, R., \& Hill, L. (2012). Konseling Karier. Yogyakarta :Pustaka Belajar.

Ningrum, S.K., \& Jati, A. (2013). Hubungan antara Efikasi Diri dengan Pengambilan Keputusan Karir pada Mahasiswa semester akhir Fakultas Ekonomi dan Bisnis Universitas Diponegoro. Empati Fak. Psikologi, 2(4), 456-464.

Santrock. (2009). Psikologi Pendidikan Educational Psychology. Jakarta: Salemba Humanika

Sarjono, H., \& Julianita, W. (2013). SPSS vs LISREL. Jakarta: Salemba Empat.

Prasetyo, B., \& Jannah, L.M. (2014). Metode Penelitian Kuantitatif. Jakarta: Rajawali Pers

Sarwono, S.W., \& Meinarno, A.K. (2009). Psikologi Sosial. Jakarta: Salemba Humanika

Siska, S.T. (2015). Hubungan Antara Efikasi diri dengan Motivasi Belajar siswa kelas $x$ SMA negeri 9 Kota Bengkulu. (Skripsi tidak dipublikasikan). Program Studi Bimbingan dan Konseling FKIP Universitas Bengkulu, Bengkulu.

Sugiyono. (2011). Metode Penelitian Pendidikan Pendekatan Kuantitatif, Kualitatif dan $R \& D$. Bandung: Alfabeta

Sunarto \& Hartono, A. (2013). Perkembangan Peserta Didik. Jakarta: Renika Cipta

Undang-Undang SISDIKNAS (Sistem Pendidikan Nasional) Tahun 2003. Jakarta: Sinar Grafika

Winkel, W.S., \& Hastuti, M.M.S. (2004). Bimbingan dan Konseling di Institusi Pendidikan. Yogyakarta: Media Abadi.

Yowell, E.B., Andrew, L., \& Buzzetta, M.E. (2010). Explaining Career Decision Making Seif Efficacy: Personality,Cognitions, and Cultural Mistrust. The Career Development Quarterly, 59(5), 400-411.

Zuriah, N. (2009). Metode Penelitian Sosial dan Pendidikan Teori-Aplikasi. Jakarta: Bumi Aksara 